\title{
An improved procedure for the assay of available lysine and methionine in feedstuffs using Tetrahymena pyriformis $\mathrm{W}$
}

\author{
BY C. SHORROCK* \\ National Institute for Research in Dairying, Shinfield, Reading RG2 $9 A T$
}

(Received 28 August I975 - Accepted ${ }_{3} 3$ October 1975)

\begin{abstract}
I. A study was made of the assay of available lysine and available methionine using Tetrahymena pyriformis $\mathrm{W}$, as applied to a variety of protein-rich feedstuffs.

2. Results were strongly influenced by the conditions under which the analyses were done. With most of the test samples predigestion with papain caused a large increase in the values obtained.

3. An improved assay procedure was developed which included enzymic predigestion of the test samples, 'all-in' sterilization of the medium constituents, and measurement of growth from extinction values. It gave results for available lysine that were broadly similar to those obtained in growth tests with rats, and in chemical tests by the method of Carpenter (1960). Values for available methionine agreed closely with those obtained in microbiological tests with Streptococcus zymogenes.
\end{abstract}

The concept of biological availability as applied to amino acids in food proteins has been much studied in recent years, and a number of biological, chemical, microbiological and enzymic methods for determining amino acid availability have been proposed.

One such method was described by Stott \& Smith (1966) who developed a procedure, based on the method of Fernell \& Rosen (1956), which uses Tetrahymena pyriformis $\mathrm{W}$ for measuring the availability of lysine, methionine, arginine and histidine in intact protein sources. The technique they used is complex but it formed the basis of the present study and was further developed empirically. The results obtained were evaluated by comparison with those from rat growth tests, from microbiological tests with Streptococcus zymogenes and with available-lysine values determined by reaction with I-fluoro-2,4-dinitrobenzene (FDNB) by the method of Carpenter (1960).

\section{MATERIALS AND METHODS}

\section{Materials}

Most of the samples used in this study have been the subject of a collaborative study on biological, chemical and microbiological methods for assessing protein quality, conducted under the aegis of the Protein Evaluation Group of the Agricultural Research Council (see Boyne, Ford, Hewitt \& Shrimpton, 1975). The samples were chosen to represent a variety of protein sources and to include a wide range of protein quality.

The samples used were as follows: FM I0I, white fish meal; FM I02, Pakistan

* Present address: Animal Production Research Unit, Private Bag 33, Gaborone, Botswana. For reprints: The Librarian, National Institute for Research in Dairying, Shinfield, Reading RG2 9 AT. 
fish meal; FM 108, Icelandic herring meal; FM I 13, Peruvian anchovy meal; FM 122 and I23, South African pilchard meals; MM ror, meat meal; HY IOI, yeast grown

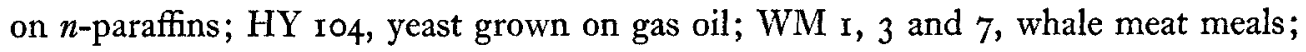
$\mathrm{CF}$, freeze-dried cod fillet (prepared as described by Ford, I965) HCF, heated cod fillet (CF heated in an air oven for $\mathrm{I} 8 \mathrm{~h}$ at $135^{\circ}$ ); SB, extracted soya-bean meal; GN, decorticated groundnut meal; vitamin-free casein.

\section{Rat growth assays}

\section{Methods}

The biological availability of lysine in ten of the test proteins was determined by the method described by Bjarnason \& Carpenter $(1969)$ and used by them to determine the biological availability of lysine in a variety of heat-damaged proteins. The potencies of the test proteins as sources of lysine were estimated by the slope-ratio technique described by Finney (1964).

\section{Chemical assays for available lysine}

The FDNB-lysine values were determined by the method of Carpenter (I960) except that the hydrolysis of the FDNB-protein complex was done using $8 \cdot \mathrm{I}$ M-hydrochloric acid, as recommended by Booth (1971).

\section{Microbiological assay procedures}

I. Assay of available lysine with Tetrahymena: preliminary tests

The assay procedure used in preliminary tests was that of Stott \& Smith (I966). The procedure for counting the numbers of organisms in the test cultures was modified; a camera attachment was fitted to the eyepiece of the microscope and each haemocytometer slide was photographed. The organisms shown on each photograph were counted with the aid of a digital counter with a marking pen attachment. This provided a simpler method of marking the cells on each photograph and counting the total numbers marked (Shorrock, 1972).

2. Modified procedure for the assay of available lysine and methionine with Tetrahymena

Assay medium. The assay medium consisted of two stock solutions, the basal medium and the amino acid supplement. The composition of the basal medium was the same as that described by Stott \& Smith (I966) except that the constituents of solutions A, $\mathrm{B}, \mathrm{C}, \mathrm{D}$ and $\mathrm{E}$, and glucose, were all dissolved into one solution which was made up at ten times the final strength. The amino acid supplement was also the same as that used by Stott \& Smith (I966) and like the basal medium it was made up at ten times the final strength, omitting either lysine or methionine.

Enzymic predigestion of test samples. In a series of tests on the effect of enzymic predigestion of the test proteins on the available lysine values, the following procedures were used.

Papain predigestion was done using $2 \mathrm{ml}$ of a $40 \mathrm{mg} / \mathrm{ml}$ suspension of crude papain (BDH Chemicals Ltd, Poole, Dorset) per $100 \mathrm{mg}$ protein-nitrogen, in $20 \mathrm{ml}$ buffer 
containing $(/ 1) 5 \mathrm{~g}$ trisodium citrate, $30 \mathrm{mg}$ sodium cyanide and sufficient of a $100 \mathrm{ml} / 1$ solution of phosphoric acid to bring the $\mathrm{pH}$ to $7 \cdot 2$. Samples were digested for either 3 or $5 \mathrm{~h}$ at $56^{\circ}$ in $28 \mathrm{~g} \mathrm{McCartney}$ bottles, with continuous 'end-over-end' shaking.

Pepsin predigestion was done by suspending a sample of test protein containing $100 \mathrm{mg}$ protein- $\mathrm{N}$ in $20 \mathrm{ml} 0.05 \mathrm{M}$-hydrochloric acid, adjusting the $\mathrm{pH}$ to $\mathrm{I} .8$ and adding $\mathrm{I} \mathrm{ml}$ of a solution of three-times-crystallized pepsin (Koch-Light Laboratories Ltd, Colnbrook, Bucks.) (10 mg/ml) in $0.05 \mathrm{M}$-hydrochloric acid. Samples were digested for $3 \mathrm{~h}$ at $56^{\circ}$ with continuous 'end-over-end' shaking. After incubation, the digests were adjusted to $\mathrm{pH} 7^{\cdot} \mathrm{I}$ and diluted to contain $300 \mu \mathrm{g} \mathrm{N} / \mathrm{ml}$.

Assay procedure. Assays were carried out in $19 \times 150 \mathrm{~mm}$ optically matched, Pyrex test-tubes held in wire baskets each holding seventy-two test-tubes. The test digests were assayed at dose levels of $0,0.5,1 \cdot 0,1 \cdot 5,2 \cdot 0,2 \cdot 5$ and $3 \cdot 0 \mathrm{ml}$, equivalent to $0,0 \cdot 15$, $0.30,0.45,0.60,0.75$ and $0.9 \mathrm{mg} \mathrm{N} /$ test-tube. The L-lysine $\mathrm{HCl}$ standard was prepared at dose levels of $0,90,180,270,360,45^{\circ}$ and $540 \mu \mathrm{g} /$ test-tube, and the Lmethionine standard at $0,40,80,120,160,200$ and $240 \mu \mathrm{g} /$ test-tube. The content of each test-tube was made up to $8 \mathrm{ml}$ by addition of distilled water. Basal medium ( $\mathrm{I} \mathrm{ml}$ ) and $\mathrm{I} \mathrm{ml}$ of the appropriate amino acid supplement were then added. The baskets of filled test-tubes were each covered with a folded cotton Terry towel which was held firmly in position by an aluminium lid, and sterilized at $110^{\circ}$ for $10 \mathrm{~min}$. After cooling, the tubes were inoculated with $0.5 \mathrm{ml}$ of a $3 \mathrm{~d}$ culture of Tetrahymena and incubated for $9^{6} \mathrm{~h}$ at $25^{\circ}$ in an air incubator, with continuous shaking. The baskets of testtubes were then heated in flowing steam for $10 \mathrm{~min}$, cooled and growth measured turbidimetrically using a colorimeter (Lumetron Model $400 \mathrm{~A}$; Photovolt Corporation, New York, USA) fitted with a $580 \mathrm{~nm}$ glass filter. An 'enzyme blank' was included with each assay. After incubation, the enzyme solution was diluted to $100 \mathrm{ml}$ and assayed at dose levels of $2 \cdot 0,2 \cdot 5$ and $3 \cdot 0 \mathrm{ml}$. The values obtained for the test samples were corrected by subtraction of this 'blank' value.

3. Assay of available methionine with Strep. zymogenes

The assay procedure was that of Ford $(1962,1964)$ modified as described by Boyne et al. (1975).

4. Assay of total lysine with Pediococcus cerevisiae P6o

The assay procedure was that of Barton-Wright (1963), except that the basal medium was modified by substituting the amino acid mixture used in the Strep. zymogenes assay procedure for that recommended by Barton-Wright ( 1963$)$. Growth responses were determined titrimetrically.

\section{EXPERIMENTAL AND RESULTS}

Results of the preliminary tests. Table I gives the available-lysine values for ten protein feedstuffs, as measured with Tetrahymena by the procedure of Stott \& Smith (1966), and the corresponding FDNB- and total-lysine values.

For most of the test samples, the Tetrahymena values were considerably lower than those given by the FDNB test; e.g. for MM IOI and HY IOI the respective values were II and 19 with Tetrahymena, and $4 \mathrm{I}$ and 57 by the FDNB test. The corresponding 
Table I. Available-lysine values $(\mathrm{g} / \mathrm{kg}$ crude protein (nitrogen $\times 6 \cdot 25))$ in a variety of food proteins, as determined microbiologically with Tetrahymena pyriformis $W$ by the method of Stott $\Xi^{\circ}$ Smith $(\mathrm{1} 966)$ and chemically by reaction with $\mathrm{1}-$ fluoro-2,4-dinitrobenzene (FDNB) (Carpenter, I960); total-lysine values, determined microbiologically with Pediococcus cerevisiae $P 60$, are also given for comparison*

(Mean values for two determinations; values in parentheses are available-lysine values expressed as a percentage of total-lysine values)

\begin{tabular}{|c|c|c|c|}
\hline \multirow[b]{2}{*}{ Sample $\nmid$} & \multicolumn{2}{|c|}{ Available lysine } & \multirow[b]{2}{*}{$\begin{array}{l}\text { Total } \\
\text { lysine }\end{array}$} \\
\hline & $\begin{array}{c}\text { Tetrahymena } \\
\text { assay }\end{array}$ & $\begin{array}{c}\text { FDNB } \\
\text { test }\end{array}$ & \\
\hline Fish meal, FM IOI & $48(66)$ & $61(85)$ & 72 \\
\hline Meat meal, MM го & II (22) & $4 \mathrm{I}(84)$ & 49 \\
\hline $\begin{array}{l}\text { Whale meat meal: } \\
\text { WM r } \\
\text { WM } 3 \\
\text { WM } 7\end{array}$ & $\begin{array}{r}12(17) \\
27(3 I) \\
8(I x)\end{array}$ & $\begin{array}{l}4 I(58) \\
6 I(69) \\
30(42)\end{array}$ & $\begin{array}{l}71 \\
88 \\
72\end{array}$ \\
\hline $\begin{array}{l}\text { Hydrocarbon yeast: } \\
\text { HY IOI } \\
\text { HY IO4 }\end{array}$ & $\begin{array}{l}\text { I9 (27) } \\
26(36)\end{array}$ & $\begin{array}{l}57(80) \\
58(80)\end{array}$ & $\begin{array}{l}71 \\
73\end{array}$ \\
\hline $\begin{array}{l}\text { Cod muscle: } \\
\text { Unheated } \\
\text { Heated }\end{array}$ & $\begin{array}{l}64(73) \\
10(14)\end{array}$ & $\begin{array}{l}85(97) \\
56(76)\end{array}$ & $\begin{array}{l}88 \\
74\end{array}$ \\
\hline Casein, vitamin-free & $82(94)$ & $84(97)$ & 87 \\
\hline
\end{tabular}

values from chick growth tests were 35 and 65 (Carpenter \& Woodham, 1974), and it seemed clear that the Tetrahymena assay underestimated the true biological availability of lysine in the test proteins.

\section{Comparison of methods for measurement of growth response in the assays, using the modified assay procedure}

A major practical disadvantage of the Tetrahymena procedures has been the need for laborious microscopic counting of the cells in the test cultures. Microscopic cell counting is tedious and time-consuming and subject to error, because it is often difficult to distinguish between cells and particles of food in the cultures. Difficulties in filling the haemocytometer sometimes occur with cultures containing particles of undigested protein, and before counting it is essential to ensure that there is uniform distribution of the organisms on the haemocytometer grating.

One result of introducing an enzymic predigestion stage was that some of the test extracts were relatively clear and free from material in suspension. With these clearer extracts it seemed that it might often be possible to assess growth simply by measuring extinction values for the test cultures rather than by counting the cells. To test this the available-lysine contents of five proteins, casein, CF, FM Iог, GN and SB, were assessed both from measurement of extinction of the cultures and by counting the number of organisms. 
Table 2. Influence of enzymic pretreatment of the test proteins on available-lysine values $(\mathrm{g} / \mathrm{kg}$ crude protein (nitrogen $\times 6 \cdot 25))$ as determined by the modified Tetrahymena pyriformis $W$ procedure ('all-in' sterilization and extinction measurements)*

(Mean values for two determinations)

\begin{tabular}{|c|c|c|c|c|}
\hline \multirow[b]{3}{*}{ Sample† } & \multirow[b]{3}{*}{ Undigested } & \multicolumn{3}{|c|}{ Predigested with: } \\
\hline & & \multirow{2}{*}{$\begin{array}{l}\text { Pepsin } \\
\text { for } \\
3 \mathrm{~h}\end{array}$} & \multicolumn{2}{|c|}{ Papain for } \\
\hline & & & $3 \mathrm{~h}$ & $5 \mathrm{~h}$ \\
\hline Fish meal, FM Ior & 20 & 53 & $5^{I}$ & 48 \\
\hline $\begin{array}{l}\text { Whale meat meal: } \\
\text { WM I } \\
\text { WM }_{3} \\
\text { WM }_{7}\end{array}$ & $\begin{array}{r}12 \\
27 \\
8\end{array}$ & $\begin{array}{l}28 \\
38 \\
15\end{array}$ & $\begin{array}{l}3 \mathbf{I} \\
39 \\
17\end{array}$ & $\begin{array}{l}33 \\
42 \\
20\end{array}$ \\
\hline Casein, vitamin-free & 77 & 75 & 76 & 75 \\
\hline
\end{tabular}

Only for GN (groundnut meal) was there any marked difference between results calculated by the two methods (extinction measurements, $54 \mathrm{~g} / \mathrm{kg}$ crude protein $(\mathrm{N} \times 6 \cdot 25)$; cell counts, $3^{6} \mathrm{~g} / \mathrm{kg}$ crude protein). The extinction value was higher than that for total-lysine content and was clearly incorrect.

Clearly for some high-protein feedstuffs, which left very little material in suspension after enzymic predigestion, it was possible to assess growth from extinction measurements of the test cultures rather than by the laborious and less precise procedure of cell counting. Thus, for FM, casein and SB the two methods gave closely similar results.

\section{Aseptic addition of culture-medium constituents}

A complication of the Tetrahymena assay procedure of Stott \& Smith (1966) is the need for separate sterilization of the culture-medium constituents. Stott \& Smith (I966) sterilized the test protein and solution $\mathrm{E}$ (nucleotides) separately from solution A (vitamins), solution F (amino acids) and glucose, to prevent possible sugar-amino acid and sugar-vitamin interactions. Although they recommended separate sterilization they did not indicate whether this had any effect on the assay. To test this point, two proteins (casein and $\mathrm{WM}_{7}$ ) were assayed for available lysine using separate sterilization and 'all-in' sterilization of the culture-medium constituents.

Separate sterilization gave better growth with the lysine standard and with casein, the difference at the upper limit of the standard range being 0.05 extinction units, equivalent to about $15 \%$ extra growth. However, the method of sterilization had no significant effect on the assay results. Calculation of the available-lysine values for casein gave 74 and $7^{6} \mathrm{~g} / \mathrm{kg}$ crude protein after 'all-in' sterilization and after separate sterilization of the medium constituents respectively; with WM 7 , the corresponding values were 22 and $23 \mathrm{~g} / \mathrm{kg}$ crude protein. 
Table 3. Available lysine ( $\mathrm{g} / \mathrm{kg}$ crude protein (nitrogen $\times 6 \cdot 25)$ ) in a variety of food proteins, as determined by the modified Tetrahymena pyriformis $W$ procedure ('all-in' sterilization and extinction measurements), by the 1-fluoro-2,4-dinitrobenzene (FDNB) test, and in rat growth assays*

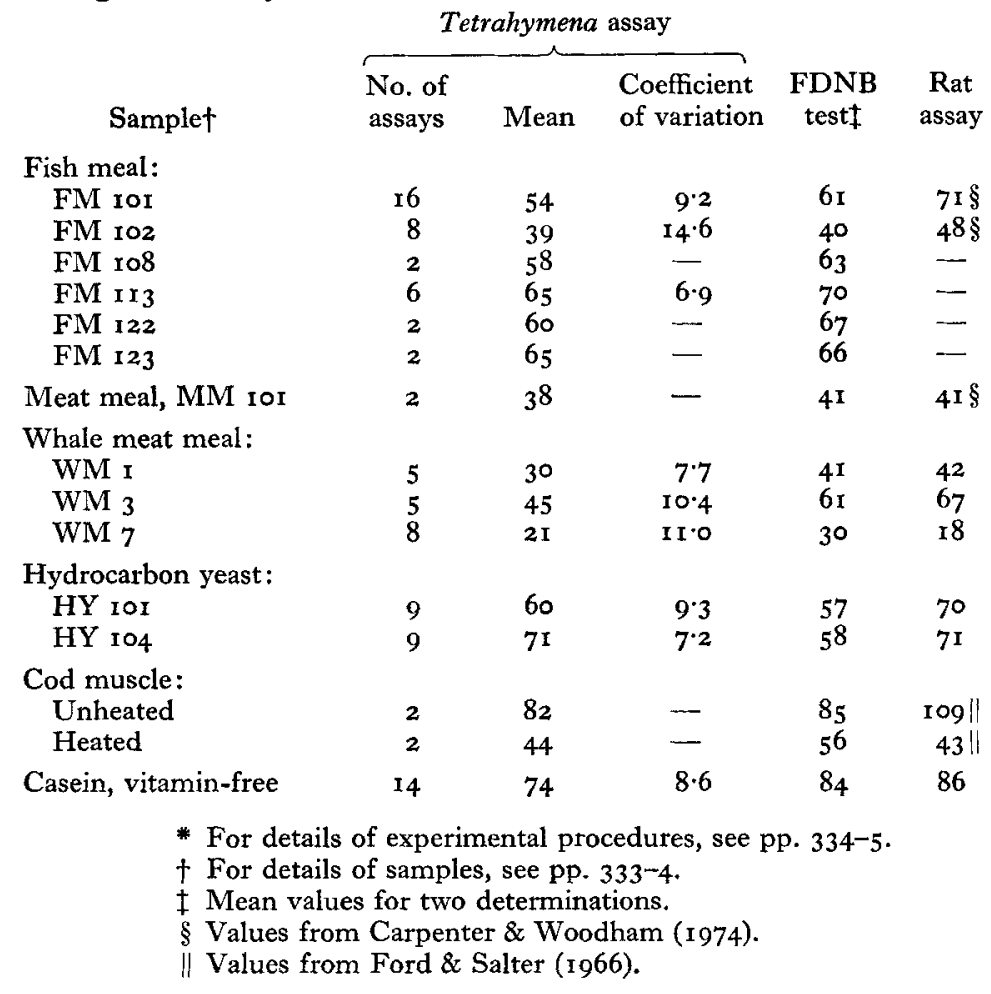

\section{Influence of enzymic predigestion of the test samples}

Results given in Table 2 indicate the influence of predigestion of the test samples with pepsin or papain on the available-lysine values obtained, using 'all-in' sterilization and extinction measurements, for casein, FM гог, WM $1, \mathrm{WM}_{3}$ and WM 7 . With all the samples except casein, the predigestion increased the available-lysine value. Pepsin and papain gave similar values, and increasing the period of incubation with papain from 3 to $5 \mathrm{~h}$ gave no consistent increase in the values.

\section{Determination of available lysine in high-protein materials}

From the preliminary tests a modified assay procedure was adopted, and used in the determination of available lysine in fifteen protein-rich feedstuffs. The test proteins were predigested for $3 \mathrm{~h}$ with papain and the assay was done in optically-matched test-tubes using 'all-in' sterilization. The results were calculated from extinction values, and are given in Table 3, together with the corresponding FDNB-lysine values, and with values from rat growth assays, for eleven of the samples.

The 'between-assay' reproducibility of the results with Tetrahymena was generally 
Table 4. Available methionine ( $\mathrm{g} / \mathrm{kg}$ crude protein (nitrogen $\times 6 \cdot 25)$ ) in a variety of food proteins, as determined microbiologically by the modified Tetrahymena pyriformis $W$ procedure ('all-in' sterilization and extinction measurements), and by the Streptococcus zymogenes assay procedure,* and in chick growth assays

(Mean values for two determinations)

\begin{tabular}{|c|c|c|c|}
\hline Sample† & $\begin{array}{c}\text { Tetrahymena } \\
\text { assay }\end{array}$ & $\begin{array}{c}\text { Strep. zymogenes } \\
\text { assay }\end{array}$ & $\begin{array}{c}\text { Chick } \ddagger \\
\text { assay }\end{array}$ \\
\hline \multicolumn{4}{|l|}{ Fish meal: } \\
\hline FM ror & 25 & 23 & 25 \\
\hline FM I02 & 16 & 17 & I 8 \\
\hline FM I08 & 24 & 24 & 20 \\
\hline FM I I3 & 29 & 26 & 22 \\
\hline FM 122 & 24 & 25 & $2 I$ \\
\hline$F M=23$ & 27 & 25 & 22 \\
\hline Meat meal, MM ror & I I & 9 & I I \\
\hline \multicolumn{4}{|l|}{ Whale meat meal: } \\
\hline WM r & 10 & II & \\
\hline $\mathrm{WM}_{3}$ & IO & I5 & \\
\hline WM 7 & 4 & 5 & \\
\hline \multicolumn{4}{|l|}{ Hydrocarbon yeast: } \\
\hline HY Ior & 15 & 16 & 9.9 \\
\hline HY 104 & I6 & I 5 & 9.9 \\
\hline \multicolumn{4}{|l|}{ Cod muscle: } \\
\hline Unheated & $3 I$ & 30 & \\
\hline Heated & 16 & 16 & \\
\hline Casein, vitamin-free & 27 & $3 I$ & \\
\hline
\end{tabular}

high, by the standard of microbiological assay. Thus, sixteen independent determinations of available lysine in FM Ior gave a mean value of $54 \mathrm{~g} / \mathrm{kg}$ crude protein, and a coefficient of variation of 9.2 . For FM 102, a poorly digestible material of low nutritional quality, the coefficient of variation was greater $(14.6)$.

The values with Tetrahymena were closely correlated with those from rat growth assays $(r 0.94, P<0.001)$, as also were the FDNB-lysine values $(r 0.93, P<0.001)$. The in vitro tests were about equally successful as predictors of the biological availability of lysine for the rat. The regression equations were as follows:

$$
\begin{aligned}
& \text { Rat assay value }=-\mathrm{r} \cdot 77+\mathrm{I} \cdot 23 \text { (Tetrahymena value), } \\
& \text { Rat assay value }=-\mathrm{I} 4 \cdot 4 \mathrm{I}+\mathrm{I} \cdot 34 \text { (FDNB value). }
\end{aligned}
$$

Total-lysine values showed no significant correlation with the rat bioassay results ( $r$ o.6I, not significant).

\section{Determination of available methionine}

The Tetrahymena assays were done using 'all-in' sterilization, and growth was calculated from extinction values. The test proteins were predigested for $3 \mathrm{~h}$ with papain. The results are given in Table 4, together with the corresponding Strep. 
zymogenes values and with values for chick growth assays for nine of the test samples.

The available-methionine values obtained by the two microbiological methods were closely correlated $(r 0.96, P<0.00 \mathrm{I})$ as also were the chick assay values with both sets of microbiological assay values. The regression equations were as follows:

Chick assay value $=0.98+0.88$ (Tetrahymena value) $(r \circ .98, P<0.001)$,

Chick assay value $=0.84+0.84$ (Strep. zymogenes value) $(r 0.98, P<0.001)$.

Both methods graded the whale meat meals in the same order, and both identified the poor-quality fish meal, FM ro2. Although the remaining fish meals were broadly similar in quality, both methods indicated that FM I I 3 was marginally superior.

\section{DISCUSSION}

Comparison of the available-lysine values determined with Tetrahymena with and without enzymic predigestion indicated clearly that the test samples must be predigested in order to obtain results in reasonable agreement with rat assay and FDNB-lysine values.

The introduction of a predigestion stage into the assay procedure improved accuracy and, by giving clearer test extracts, allowed the use of extinction values as a measure of growth for some materials of high protein content. But with GN it proved necessary to assess growth by the cell counting method, and with some samples of SB the test digests were distinctly turbid and it was clearly not permissible to assess growth photometrically. Shepherd, Taylor \& Wilton (1975) found that it was possible to determine growth of Tetrahymena by the estimation of tetrahymanol, a specific sterol produced by the organism. This is a promising development, but the assay of tetrahymanol prolongs and complicates the assay procedure. The same workers also found that in order to obtain available-lysine values in agreement with values obtained by chick bioassay it was essential to predigest the test samples with a protease (pronase).

Although the coefficient of variation for available-lysine values as measured with Tetrahymena was greater than that reported by Booth (197I) for the FDNB procedure $(3.8)$, the microbiological test has the advantage that it does not tend to over-estimate the availability of lysine in heat-damaged proteins. Ford (1964) commented on this apparent tendency. He pointed out that the chemical test takes no account of digestibility and suggested that lysine moieties reacting as 'available' in the chemical test might remain in indigestible peptide residues and be unavailable to the animal.

Tetrahymena and Strep. zymogenes gave essentially the same values for available methionine, but the Strep. zymogenes method offers several advantages. It is quicker $(48 \mathrm{~h} v .96 \mathrm{~h}$ ) and it is more easily applied to samples rich in carbohydrate, as growth can be assessed not only from the extinction measurements but also from the acid produced during the growth of the test cultures. The Strep. zymogenes test is also more sensitive, but Tetrahymena offers the compensating advantage that it can be used to measure both lysine and methionine in the same test extract. 
The experiments described above using a modified Tetrahymena procedure are encouraging in that the values reported are in general agreement with published work on the available amino acid values of a similar range of proteins (cf. Boyne, Price, Rosen \& Stott, 1967). In general, the findings indicate that the Tetrahymena assay can predict accurately the results of growth tests with rats but it would be premature to recommend the present assay procedure for routine use. Further development is still needed, and in particular, the problem of finding a quicker alternative to cell counting remains to be solved.

The author is grateful to Dr J. W. G. Porter for helpful discussion and to Dr J. E. Ford for advice and encouragement in this work.

\section{REFERENCES}

Barton-Wright, E. C. (1963). Practical Methods for the Microbiological Assay of the Vitamin B Complex and Amino Acids. London: United Trade Press Ltd.

Bjarnason, J. \& Carpenter, K. J. (г969). Br. F. Nutr. 23, 859.

Booth, V. H. (1971). F. Sci. Fd Agric. 22, 658.

Boyne, A. W., Ford, J. E., Hewitt, D. \& Shrimpton, D. H. (1975). Br. F. Nutr. 34, I53.

Boyne, A. W., Price, S. A., Rosen, G. D. \& Stott, J. A. (1967). Br. J. Nutr. 21, I8I.

Carpenter, K. J. (1960). Biochem. F. 77, 604.

Carpenter, K. J. \& Woodham, A. A. (1 974). Br. F. Nutr. 32, 647.

Fernell, W. R. \& Rosen, G. D. (1956). Br. F. Nutr. 10, r 43 .

Finney, D. J. (1964). Statistical Method in Biological Assay, and ed. New York: Hafner Publishing Co.

Ford, J. E. (1962). Br. F. Nutr. 16, 409 .

Ford, J, E. (1964). Br. F. Nutr. 18, 449.

Ford, J. E. (1965). Br. F. Nutr. 19, 277.

Ford, J. E. \& Salter, D. N. (1966). Br. F. Nutr. 20, 843 .

Shepherd, N. D., Taylor, T. G. \& Witton, D. C. (I975). Proc. Nutr. Soc. 34, rooA.

Shorrock, C. (1972). Studies on the biological availability of amino acids in feedstuffs. PhD Thesis, University of Reading.

Stott, J. A. \& Smith, H. (1966). Br. Y. Nutr. 20, 663. 